\title{
Integrated Renewable Energy Sources for Decentralized Systems in Developing Countries
}

\author{
Olumuyiwa O. Fagbohun ${ }^{1}$ and Bankole A. Adebanji \\ ${ }^{1}$ Department of Electrical\& Electronic Engineering,Faculty of Engineering, Ekiti State University, Ado-Ekiti, \\ Ekiti - State, Nigeria.
}

\begin{abstract}
Renewable energy is sustainable, inexhaustible and can easily be set up in small unitsand is therefore, suitable for community management and ownership. However, a very serious threat to grassroots utilization of renewable energy in rural areas is the lack of large and effective infrastructures to generating changes in renewable energy technologies. Moreover, most of the renewable energy sources being used in the rural areas have failed in matching supply with demand due to their stochastic or seasonal variations. There is need for educational institutions to involve in aggressive research in renewable energy technologies tailored using locally available renewable energy sources and training of personnel to do the jobs in developing countries. This paper presents the overall review of renewable energy technologies available for use in rural areas, stressed the need for collaborative efforts between the governments, communities and educational institutionsand discussed on design considerations for integrated rural energy systems and small hydro/PV hybrid system for a typical rural community in Nigeria.
\end{abstract}

Keywords:Integrated renewable energy systems, hybrid systems, small hydropower, solar PV

\section{Introduction}

Access to energy is fundamental for socio-economic development and poverty alleviation. Developing countries all over the world, are characterized by; low per capita energy consumption most of which goes in cooking and lighting; high unemployment in rural areas; rural areas largely dependent on biomass energy sources and large difference in living standards ofurban and rural population[1].

Interests in the utilization of renewable energy sources in most developing countries of the world have continued to be on increase. However, lack of large and effective infrastructures dedicated to generating changes poses a serious threat to grassroots utilization of renewable energy in rural areas. The success of systems introduced to harness renewable energy sources in the rural areas of developing countries will primarily depend on development and availability of appropriate technologies, hardware, and design methodologies to match the resources to the needs $[1,2,3]$. The buildup of educational services and the associated infrastructure necessary to properly maintain and utilize the systems that are already installed are very important for any meaningful development in the rural setting. It is very important for energy planning in any developing country to determine what can be done at home andwhat is not practical to do at home. In all of these areas, educational institutions can play a key role. Integrated use of renewable energy sources will help overcome weakness of one resource by the strength of the other in some aspects. This will also provide job opportunities and upgrades socio-economic conditions of rural communities.

Rural dwellers' energy needs are for basic livingactivities, agricultural production and establishment of small -scale industries.Research on the development of the world's energy state and the future development showed that almost two billion people world-wide do not have access to modern energy services. This lack of access to electricity mainly applies to rural areas in developing countries,and progress being made over the last 25 years has applied mainly to urban areas. It is saddening to note that without central governments taking heavy financial initiatives, the situation in 2030 will remain more or less unchanged with 1.4 billion people or $18 \%$ of the world's population without electricity supply [3,4].

Electrification of a rural society is not the efficient and economical way to achieve asustainable society. Electrical load in remote areas is very small as compared to otherenergy needs such as cooking, heating etc. Hence, rural electrification is not the idealsolution in these areas. Providing energy needs in various forms to match the needsallows the end users to benefit from such system [3,4,5].Even today, people in rural areas use traditional biomass such as firewood, animal dung, straw, and charcoal to satisfy their daily energy needs. They use animal dung, charcoal, firewood, etc. for cooking, kerosene for lighting purposes and expensive dry cell batteriesfor communication purposes. These pose threat not only to the surrounding environmentbut also to their health. Therefore, renewable energy technologies must be promoted toplay a vital role to improve their quality of life and provide a sustainable and safe environment to live [6]. 


\section{Methodology of Research}

The study started with detailed studies of the available literature on different renewable energy technologies. Relevant information on the status of renewable energy in Nigeria was sourced from the Energy Commission. Primary and secondary data of stream flow,head and hydrographs for the past ten years were sourced from the water Corporation during visitation to the site. The solar irradiation data were collected from Nigerian Meteorological centre. This was analyzed using analytical method-Angstrom model. The load demand estimation model were done through questionnaires and personal visitation. The load demand profile was then compared with the total capacity power of the SHP/PV hybrid system.

\section{Overview of Renewable Energy Conversion Technologies}

All renewable energy sources can be converted to electricity. However,in practical terms there will be some routes that will be preferred due to its cost -effectiveness. These are subsequently discussed in the following sections.

\subsection{Biomass}

Biomassis biological material derived from living, or recently living organisms. It most often refers to plants or plant-based materials which are specifically called lingo-cellulosic biomass[7,8]. As an energy source, biomass can either be used directly via combustion to produce heat, or indirectly after converting it to various forms ofbiofuel. Conversion of biomass to biofuel can be achieved by different methods which are broadly classified into: thermal, chemical, and biochemical methods. Wood remains the largest biomass energy source to date[9] examples include forest residues (such as dead trees, branches and tree stumps), yard clippings, wood chips and even municipal solid waste. In the second sense, biomass includes plant or animal matterthat can be converted into fibers or other industrial chemicals, including biofuels. Industrial biomass can be grown from numerous types of plants, including miscanthus, switchgrass, hemp, corn,poplar, willow, sorghum, sugarcane, bamboo[7,10], and a variety of tree species, ranging from eucalyptus to oil palm (palm oil).

Biomass can be converted to other usable forms of energy like methane gas or transportation fuels like ethanol and biodiesel. Rotting garbage, and agricultural and human waste, all release methane gas - also called "landfill gas" or "biogas." Crops, such as corn and sugar cane, can be fermented to produce the transportation fuel, ethanol. Biodiesel, another transportation fuel, can be produced from left-over food products like vegetable oils and animal fats[8.] The biomass used for electricity generation varies by region. Forest by-products, such as wood residues, are common in the United States. Agricultural waste is common in Mauritius (sugar cane

residue) and Southeast Asia (rice husks). Animal husbandry residues, such as poultry litter, are common in the $\mathrm{UK}[10,11]$.Direct combustion remains the most common technique for deriving energy from biomass for both heat and electricity production. The different technologies tend to be classed in terms of either the conversion process they use or the end product produced. Combustible gas can also be produced from biomass through the low temperature biological processes called anaerobic (without air) digestion. The biogas produced can be burned to provide energy for cooking and space heating or to generate electricity. Other known areas of applications are in fermentation of biomass to produce alcohols,pyrolysis to produce liquid and gaseous anaerobic fermentation of human, animal and agricultural wastes to produce biogas for several uses.

\subsection{Wind Energy}

Wind power is the conversion of wind energy into a useful form of energy, such as using wind turbines to produce electrical power, windmills for mechanical power, windpumps for water pumping or drainage, or sails to propel ships. Wind power is very consistent from year to year but has significant variation over shorter time scales. Unlike fueled generating plants, the capacity factor is affected by several parameters, including the variability of the wind at the site and the size of the generator relative to the turbine's swept area. A small generator would be cheaper and achieve a higher capacity factor but would produce less electricity (and thus less profit) in high winds. Conversely, a large generator would cost more but generate little extra power and, depending on the type, may stall out at low wind speed. Thus an optimum capacity factor of around $40-50 \%$ would be aimed for $[11,12]$.

Solar power tends to be complementary to wind[13]. On daily to weekly timescales, high pressure areas tend to bring clear skies and low surface winds, whereas low pressure areas tend to be windier and cloudier. On seasonal timescales, solar energy peaks in summer, whereas in many areas wind energy is lower in summer and higher in winter[11,13]. Thus the intermittencies of wind and solar power tend to cancel each other.

Wind power is capital intensive, but has no fuel costs [14]. The price of wind power is therefore much more stable than the volatile prices of fossil fuel sources [14]. The marginal cost of wind energy once a plant is constructed is usually less than 1-cent per $\mathrm{kW} \cdot \mathrm{h}[12]$. This cost has additionally reduced as wind turbine technology hasimproved. There are now longer and lighter wind turbine blades, improvements in turbine performance and increased power generation efficiency. Also, wind project capital and maintenance costs have 
continued to decline[13]. Small-scale wind power is the name given to wind generation systems with the capacity to produce up to $50 \mathrm{~kW}$ of electrical power[13,15]. Isolated communities that may otherwise rely on diesel generators may use wind turbines as an alternative. Individuals may purchase these systems to reduce or eliminate their dependence on grid electricity for economic reasons, or to reduce their carbon footprint. Wind turbines have been used for household electricity generation in conjunction with battery storage over many decades in remote areas $[13,14]$. Recent examples of small-scale wind power projects in an urban setting can be found in New York City, where, since 2009, a number of building projects have capped their roofs with Gorlovtype helical wind turbines. Although the energy they generate is small compared to the buildings' overall consumption, they help to reinforce the building's 'green' credentials in ways that "showing people your hightech boiler" cannot, with some of the projects also receiving the direct support of the New York State Energy Research and Development Authority [11].

Grid-connected domestic wind turbines may use grid energy storage, thus replacing purchased electricity with locally produced power when available. The surplus power produced by domestic microgenerators can, in some jurisdictions, be fed into the network and sold to the utility company, producing a retail credit for the

Micro-generators' owners to offset their energy costs[11,13]. Off-grid system users can either adapt to intermittent power or use batteries, photovoltaic or diesel systems to supplement the wind turbine. Equipment such as parking meters, traffic warning signs, street lighting, or wireless Internet gateways may be powered by a small wind turbine, possibly combined with a photovoltaic system, that charges a small battery replacing the need for a connection to the power grid[14,15]. A Carbon Trust study into the potential of small-scale wind energy in the UK, published in 2010 , found that small wind turbines could provide up to 1.5 terawatt hours (TW·h) per year of electricity ( $0.4 \%$ of total UK electricity consumption), saving 0.6 million tons of carbon dioxide (Mt CO2) emission savings. This is based on the assumption that $10 \%$ of households would install turbines at costs competitive with grid electricity, around 12 pence (US 19 cents) a $\mathrm{kW} \cdot \mathrm{h}[13,15]$. A report prepared for the UK's government-sponsored Energy Saving Trust in 2006, found that home power generators of various kinds could provide 30 to $40 \%$ of the country's electricityneeds by $2050[14,15]$. Compared to the environmental impact of traditional energy sources, the environmental impact of wind power is relatively minor in terms of pollution. Wind power consumes no fuel, and emits no air pollution, unlike fossil fuel power sources. The energy consumedto manufacture and transport the materials used to build a wind power plant is equal to the new energy produced by the plant within a few months. While a wind farm may cover a large area of land, many land uses such as agriculture are compatible, with only small areas of turbine foundations and infrastructure made unavailable for use[11,13,15].

\subsection{Geothermal Energy}

Geothermal energyis thermal energy generated and stored in the Earth. Thermal energy is the energy that determines the temperature of matter. The geothermal energy of the Earth's crust originates from the original formation of the planet (20\%) and from radioactive decay of minerals $(80 \%)[16,17]$. The geothermal gradient, which is the difference in temperature between the core of the planet and its surface, drives a continuous conduction of thermal energy in the form of heat from the core to the surface.Earth's internal heat is thermal energy generated from radioactive decay and continual heat loss from Earth's formation[18]. Temperatures at the core-mantle boundary may reach over $4000{ }^{\circ} \mathrm{C}\left(7,200{ }^{\circ} \mathrm{F}\right)[3]$. The high temperature and pressure in Earth's interiorcause some rock to melt and solid mantle to behave plastically, resulting in portions of mantle convecting upward since it is lighter than the surrounding rock. Rock and water is heated in the crust, sometimes up to $370^{\circ} \mathrm{C}\left(700^{\circ} \mathrm{F}\right)[16,18]$. From hot springs, geothermal energy has been used for bathing since Paleolithic times and for space heating since ancient Roman times, but it is now better known for electricity generation.

Worldwide, 11,400 megawatts (MW) of geothermal power is online in 24 countries in 2012[19]. An additional 28 gigawatts of direct geothermal heating capacity is installed for district heating, space heating, spas, industrial processes, desalination and agriculturalapplications in 2010[20]. Geothermal power is cost effective, reliable, sustainable, andenvironmentally friendly[16,19], but has historically been limited to areas near tectonic plate boundaries. Recent technological advances have dramatically expanded the range and size of viable resources, especially for applications such as home heating, opening a potential for widespread exploitation. Geothermal wells release greenhouse gases trapped deep within the earth, but these emissions are much lower per energy unit than those of fossil fuels. As a result, geothermal power has the potential to help mitigate global warming if widely deployed in place of fossil fuels.

The Earth's geothermal resources are theoretically more than adequate to supply humanity's energy needs, but only a very small fraction may be profitably exploited. Drilling and exploration for deep resources is very expensive. Forecasts for the future of geothermal power depend on assumptions about technology, energy prices, subsidies, and interest rates. Pilot programs like EWEB's customer opt in Green Power Program [20] 
show that customers would be willing to pay a little more for a renewable energy source like geothermal.The thermal efficiency of geothermal electric plants is low, around $10-23 \%$, because geothermal fluids do not reach the high temperatures of steam from boilers. The laws of thermodynamics limits the efficiency of heat engines in extracting useful energy. Exhaust heat is wasted, unless it can be used directly and locally, for example in greenhouses, timber mills, and district heating. System efficiency does not materially affect operational costs as it would for plants that use fuel, but it does affect return on the capital used to build the plant. In order to produce more energy than the pumpsconsume, electricity generation requires relatively hot fields and specialized heat cycles [21]. Because geothermal power does not rely on variable sources of energy, unlike, for example, wind or solar, its capacity factor can be quite large - up to $96 \%$ has been demonstrated[16,19]. The global average was $73 \%$ in 2005.Geothermal power requires no fuel (except for pumps), and is therefore immune to fuel cost fluctuations. However, capital costs are significant. Drilling accounts for over half the costs, and exploration of deep resources entails significant risks. A typical well doublet (extraction and injection wells) in Nevada can support 4.5 megawatts (MW) and costs about $\$ 10$ million to drill, with a $20 \%$ failure rate[17].

Geothermal power is considered to be renewable because any projected heat extraction is small compared to the Earth's heat content. The Earth has an internal heat content of 1031 joules $(3 \cdot 1015 \mathrm{TW} \cdot \mathrm{hr})[22]$. About $20 \%$ of this is residual heat from planetaryaccretion, and the remainder is attributed to higher radioactive decay rates that existed in the past $[20,21]$. Natural heat flows are not in equilibrium, and the planet is slowly cooling down on geologic timescales. Human extraction taps a minute fraction of the natural outflow, often without accelerating it. Geothermal power is also considered to be sustainable thanks to its power to sustain the Earth's intricate ecosystems. By usinggeothermal sources of energy present generations of humans will not endanger the capability of future generations to use their own resources to the same amount that those energy sources are presently used. Further, due to its low emissions geothermal energy is considered to have excellent potential for mitigation of global warming[19,21].

\subsection{Small hydro power(SHP)}

Small hydrois the development of hydroelectric power on a scale serving a small community or industrial plant. The definition of a small hydro project varies but a generating capacity of up to 10 megawatts (MW) is generally accepted as the upper limit of what can be termed small hydro.This may be stretched up to 30 MW in the United States, and 50 MW in Canada [1,3]. In contrast many hydroelectric projects are of enormous size, such as the generating plant at the Hoover Dam of 2,074 MW or the vast multiple projects of the Tennessee Valley Authority. Small hydro can be further subdivided into mini hydro, usually defined as less than $1,000 \mathrm{~kW}$, and micro hydro which is less than $100 \mathrm{~kW}$. Micro hydro is usually the application of hydroelectric power sized for smaller communities, single families or small enterprise. Small hydro plants may be connected to conventional electrical distribution networks as a source of low-cost renewable energy. Alternatively, small hydro projects may be built in isolated areas that would be uneconomic to serve from a network, or in areas where there is no national electrical distribution network. Since small hydro projects usually have minimal reservoirs and civil construction work, they are seen as having a relatively low environmental impact compared to large hydro $[3,5,23]$.This decreased environmental impact depends strongly on the balance between stream flow and power production. One tool that helps evaluate this issue is the Flow Duration Curve or FDC. The FDC is a Pareto curve of a stream's daily flow rate vs. frequency [24]. Reductions of diversion help the river's ecosystem, but reduce the hydro system's Return on Investment(ROI).

Small hydro is often developed using existing dams or through development of new dams whose primary purpose is river and lake water-level control, or irrigation. Occasionally old, abandoned hydro sites may be purchased and re-developed, sometimes salvaging substantialparts of the installation such as penstocks and turbines, or sometimes just re-using the water rights associated with an abandoned site. Either of these cost saving advantages can make the ROI for a small hydro site well worth the use of existing site infrastructure \& water rights. Since small hydro projects usually have minimal environmental and licensing procedures, and since the equipment is usually in serial production, standardized and simplified, and since the civil works construction is also small, small hydro projects may be developed very rapidly $[25,26]$. The physically small size of equipment makes it easier to transport to remote areas without good road or rail access.Hydropower, under the right circumstances, can be one of the most reliable andcost-effective renewable energy sources. SHP installations commonly last without the need formajor replacement costs for $30+$ years. Within the limits of water resources available,SHP installations are characterized by reliability and flexibility of operation,including fast start-up and shut-down in response to rapid demand changes. SHPelectricity can be tailored to the needs of the end-use market, avoiding balanceand power reliability concerns[3,24,27]. One major shortcoming of SHP is the seasonal variation of water especially during the dry season-it may stop or lower down due to low water in the river. 


\subsection{Solar Energy}

Solar energy is the conversion of sunlight into electricity, either directly using photovoltaic (PV), or indirectly using concentrated solar power (CSP). Concentrated solar power systems use lenses or mirrors and tracking systems to focus a large area of sunlight into a small beam. Photo-voltaic convert light into electric current using the photovoltaic effect[3,28]. Photo-voltaic were initially, and still are, used to power small andmedium-sized applications, from the calculator powered by a single solar cell to off-grid homes powered by a photovoltaic array. They are an important and relatively inexpensive source of electrical energy where grid power is inconvenient, unreasonably expensive to connect, or simply unavailable. However, as the cost of solar electricity is falling, solar power is also increasingly being used even in grid-connected situations as a way to feed low-carbon energy into the grid [29].Concentrating Solar Power (CSP) systems use lenses or mirrors and tracking systems to focus a large area of sunlight into a small beam. The concentrated heat is then used as a heat source for a conventional power plant. A wide range of concentrating technologies exists: the most developed are the parabolic trough, the concentrating linear fresnel reflector, the Stirling dish and the solar power tower. Various techniques are used to track the sun and focus light. In all of these systems a working fluid is heated by the concentrated sunlight, and is then used for power generation or energy storage[29,30]. Thermal storage efficiently allows up to 24 hourelectricity generation[27,30]. Solar photovoltaic technology is one of the first among several renewable energy technologies that have been adopted worldwide for meeting the basic needs of electricity particularly in remote areas [31].The ongoing use of PV technologies in space, their present-day cost and performance will make them suitable for many grid-isolated and even grid connected applications in both developed and developing parts of the world.Nowadays, the cost of PV system has been reduced to a relatively low level $[30,32]$. However, the stochastic nature of solar PV is still a major setback in maintaining a continuous supply during raining season.

\section{IV.Integrated System Concepts}

The objective of this concept is to supply the basic needs of the rural populace in the most economic and appropriate manner. In other words, the available resources and the energy conversion devices should be matched to the basic needs to achieve an improvement in the living environment in rural areas. Various technologies and techniques can be used to harness available renewable energy sources. The two approaches, integrated and hybrid systems, are subsequentlydiscussed below.

\subsection{Integrated Renewable Energy System (IRES)}

Since different energy needs require different forms and quality, utilization of locally renewable energy resources on end use technologies are made possible at the grassroots' levels to satisfy a variety of needs. However, this approach requires a careful and strategic planning for matching needs and available resources to maximize benefits and end use efficiencies. IRES has the potential to aggregate benefits resulting from the combination of renewable energy, energy efficiency and energy conservation [33,34].It can be seen in Fig.1, where various means of supplying the basic energy needs of a typical rural village is combined with the aim of maximizing the economic benefits. The biogas can be used to supply directly the gas needed for cooking and internal combustion engine while the solar collectors through the inverter can be converted to electricity. Exploration of the available run-of-river type of small hydropower or micro-hydropower depending on the head and flow rate,can be used for generate electricity and this can be re-cycled to supply drinking water through the treatment plant and if need arises, the irrigation schemes.

Integrated approach is suitable in rural areas where biomass is in abundance and solar, wind and hydro may be sparsely available depending on the terrain and other geographical factors.Integrated use of renewable energy sources will help overcome weakness of one resource by the strength of the other in some aspects. This will also provide job opportunities and upgrades socio-economic conditions of rural communities. 


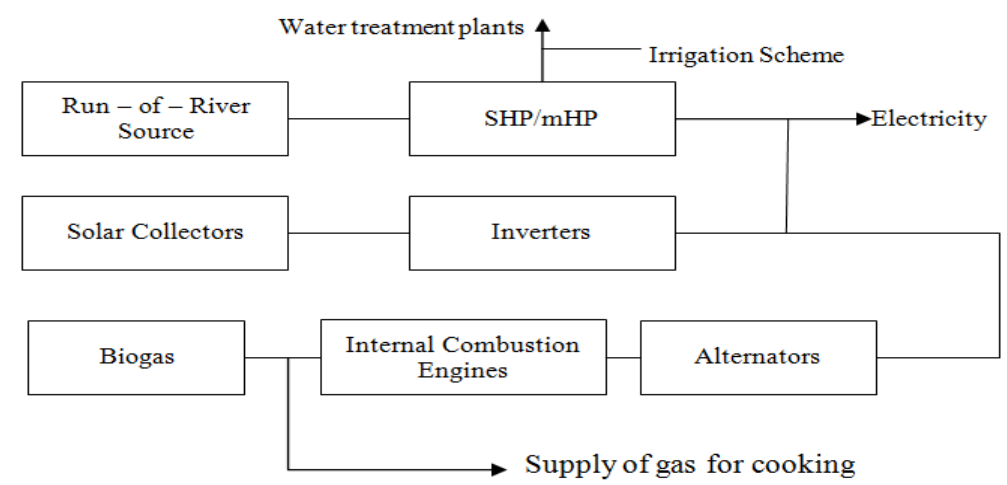

Figure 1: Schematic diagram of a typical rural energy supply.

\subsubsection{Development of Economic Cost Function}

The availability of renewable power depends upon the resources potential and size of the system. The sizing for integrated renewable energy systems (IRES) depends on the uses of the system (load on the system) and the tariffs available from the local utility [35].Renewable energy systems are, in general, characterized by high capital costs, low Operation and Maintenance (O\&M) costs, and zero fuels cost except biomass. The unit cost of energy generated by a non-burning fuel renewable energy system is obtained by considering the capital recovery cost and operation and maintenance cost. It has been computed by [35], using the following expression:

$$
C=\left[\frac{\mathrm{r}(1+\mathrm{r})^{\mathrm{n}}}{(1+\mathrm{r})^{\mathrm{n}}-1}\right]\left[\frac{\mathrm{P}}{87.6 \mathrm{k}}\right]+[0 \& M] \ldots \ldots .
$$

Where $\mathrm{C}$ is Cost of Energy, $\mathrm{n}$ is Amortization period (in years), $\mathrm{O} \& \mathrm{M}$ is Operation and Maintenance cost, $\mathrm{P}$ is Capital cost, $\mathrm{r}$ is Fixed annual interest and $\mathrm{k}$, Annual capacity factor,is

$\frac{\text { EnergygeneratedinkWh/year }}{(\text { SystemratinginkW })(8760 h / \text { year })} \ldots \ldots \ldots \ldots \ldots$.

In case of biomass gasification, the cost of biomass and Diesel fuel is to be added as $(0.3413 \mathrm{f} / \mathrm{n})$ to theequation (2) and can be written as:

$$
C=\left[\frac{r(1+r)^{n}}{(1+r)^{n}-1}\right]\left[\frac{P}{87.6 k}\right][O \& M]+\frac{0.3413 f}{n} \ldots \ldots \ldots
$$

Where $\mathrm{f}$ is Fuel cost in $£$ s. per million Btu at thegeneration site, and $\eta$ is Overall efficiency of theplant.

\subsubsection{Design considerations of IRES}

One of the major challenges faced by designers of IRES is the stochastic and site specific nature along with its attendant different types and qualities of energy demand.There is need to minimize the capital cost of the project due to the high cost of the hardware, especially for developing countries where poverty is predominant. Also,there is need for interaction among different technologies and the alternate uses of resources. The designer needs to be able to evaluate the quality and quantity of energy needs on the available renewable energy resources available in a particular area in order to optimize the design. Where the available total resources are in short supply,he/she must be able to choose the most urgent according to the priority so as to satisfy the need of so many[36].

\subsection{Hybrid Renewable Energy System (HRES)}

Hybrid renewable energy system (HRES) combines two or more energy resources and these resources are converted to one form of energy, typically electrical (DC or AC) for aggregation and distribution to customers [36]. These systems use different energy generators in combination, by this maintaining a stable energy supply in times of shortages of one of the energy resources. It has good potential for economic 
development [36,40].Technically, appropriate maintenance structures are the main aspects to be considered, requiring the establishment of maintenance Centre's. It is therefore recommendable to apply hybrid systems in areas with a significant number of villages, which are to be electrified with these systems, in order to improve financial sustainability of these maintenance Centre's. A few examples of HRES are PV/wind electric system, wind/diesel generator system, wind/PV/fuel cell hybrid system, biomass/wind/fuel cell system etc. Most of the hybrid systems use diesel generator as a backup generator. Hybrid power systems can offer solutions and value to customers that individual technologies cannot match. Low end-use efficiency and high capital cost of HRES make it unsuitable for implementation in rural areas[40].

\subsubsection{Design considerations for Small Hydropower/PV hybrid energy system for a typical rural Community}

Small hydropower plants installed in most rivers cannot meet the load demand of the villagesthroughout the year due to the seasonal variation of the water level which reduces the head and decreased flow rate especially during the dry season.A photovoltaic (PV) system with battery is a suitable option to complement the electricity gap [1,3].Nigeria is naturally blessed with a very good level of solar irradiation and adequate hydro potential in a number of locations.

In order to design and analyze a small hydro/PV hybrid system, a typical data for power consumption, hydrology and meteorological data are necessary. Sizing of stand-alone small hydro/PV hybrid system is an important part of its design. Since the capital equipment cost is the major component of the price of the electricity, oversizing the plant will have detrimental effect on the pricing of the generated power. Under sizing the system, on the other hand reduces the supply reliability.The sizing of the system requires knowledge of the load profile, the solar and water resources and the importance of supply continuity [27,31].

\subsection{Small hydro power (SHP)}

The first thing to do before embarking on SHP on rivers, there is need to do a thorough feasibility study to ensure that water are available for generation of electricity. The hydraulic power available from a river is related tothe head, flow rate, and the force of gravity as given by equation $4[33]$.
Hydraulic power $=\rho * Q * g * H g$.....
4

The electric power in $\mathrm{kW}$ is given as in equation 5

Electric power $(\mathrm{k} \mathrm{W})=$ Hydraulic power $* e=\rho * Q * g * H g * e \ldots \ldots \ldots \ldots$

$$
\begin{gathered}
\rho \text { waterspecificdensity }\left(1 \frac{\mathrm{kg}}{\mathrm{m}^{3}} \mathrm{atC}^{0}\right) \\
\text { QFlowrate, quantityof waterflowingintoturbine }\left(\frac{\mathrm{m}^{3}}{\text { second }}\right) \\
\text { ggravitationalconstant }\left(9.81 \mathrm{~m} / \mathrm{s}^{2}\right. \\
\text { Hggrossheadinmetres }
\end{gathered}
$$

Technical considerations should be given to maintaining a steady flow of atintake, proper placement of power house, and optimal choice of turbine and generator based on the current technological trends. The average annual energy should be estimated in order to calculate the estimated hydro energy cost (Naira/k W h).This cost will be compared with the cost of alternative sources of power such as solar,wind and utility supply $[26,28]$.In a typical rural community,Oye,Nigeria, where a SHP plant is to be installed,the present population of the community is 7240 with about 750 households at an average of 10 persons per household. The estimated generated power from SHP using equation 4 with an average flow rate of $12.5 \mathrm{~m}^{3} / \mathrm{s}$ and a net head of $22.5 \mathrm{~m}$, system efficiency is 0.7

$\mathrm{P}_{\text {hydro }}=0.7 \times 9810 \times 12.5 \mathrm{~m}^{3} / \mathrm{s} \times 22.5=1.83 \mathrm{MW}$

The load demand of the community was estimated to be 2.0MW.It is obvious that the SHP cannot meet the load demand and may not be able to guarantee energy security all the time especially during dry season.

\subsection{Photovoltaic (PV)}

The major components for solar PV system are solar charger controller, inverter,battery bank,auxiliary energy sources and appliances.Correct meteorological measurement through data collection as well as direct observation of solar radiation should be done.Lowest monthly inclined solar energy should be used as the basis for the design $[3,26]$.

According to reference [25], the I.V. characteristics equation of a PV cell is given by equation 6

$$
I=I_{l}-I_{s}\left(e^{\frac{q * v}{* * T}}-1\right)
$$

The maximum power provided by an ideal PV cell characteristic can be expressed as in equation 7

$$
P_{\max }=I_{s c} * V_{o c} \ldots \ldots \ldots \ldots \ldots \ldots
$$


Open -circuit voltage of a PV cell is determined by setting $\mathrm{I}=0$ in the $\mathrm{I}-\mathrm{V}$ characteristic and it is given as in equation 8

$$
\mathrm{V}_{\mathrm{oc}}=\mathrm{k} * \frac{\mathrm{T}}{\mathrm{q}} * \ln \left(1+\frac{\mathrm{I}_{1}}{\mathrm{I}_{\mathrm{s}}}\right) \cong \mathrm{k} * \frac{\mathrm{T}}{\mathrm{q}} * \ln \left(\frac{\mathrm{I}_{1}}{\mathrm{I}_{\mathrm{s}}}\right) \ldots \ldots \ldots \ldots \ldots . . . \quad 8
$$

A fill factor which is a measure of the quality of the cell,should be multiplied by $\mathrm{P}_{\max }$. Hence the maximum power from a cell expresses is as inequation 9

$$
\mathrm{P}_{\max }=\text { Fillfactor } * \mathrm{I}_{\mathrm{sc}} * \mathrm{~V}_{\mathrm{oc}} \ldots \ldots \ldots \ldots \ldots . . \ldots
$$

kBoltzmanconstant $\left(1.38047 \mathrm{X} 10^{-23} \mathrm{JK}\right)$ qelectroniccharge $\left(1.60210 \times 10^{-19} \mathrm{C}\right.$

$\mathrm{T} \quad 273 .+\mathrm{t}_{\mathrm{c}}$ isabsolutegivenasfunctionofthetemperatureinC vvoltageacrosssthePVcell

$\mathrm{I}_{\mathrm{s}}$ reversesaturatedcurrentofthediode, typically100pAforSiliconcell $\mathrm{I}_{1}$ cellcurrentduetophotons

The capacity calculation for the solar power is given by $[14,17]$ as in equation 10

$$
\mathrm{P}_{\text {solar }}=\text { AreapersqftXWattspersqft } \ldots \ldots \ldots \ldots \ldots \ldots . . . . .10
$$

Considering an area of (100ftx $100 \mathrm{ft})$ and assuming that the solar panel will produce about 9 watts per square foot of area.The generated power from the solar can be calculated as

$$
\mathrm{P}_{\text {solar }}=100 \times 100 \times 9=0.09 \mathrm{MW}
$$

So the total expected power from the proposed a SHP/Solar PV hybrid system is

$$
\begin{array}{r}
\mathrm{P}_{\text {total }}=\mathrm{P}_{\text {solar }}+\mathrm{P}_{\text {hydro }} \\
=1.93+0.09=2.02 \mathrm{MW}
\end{array}
$$

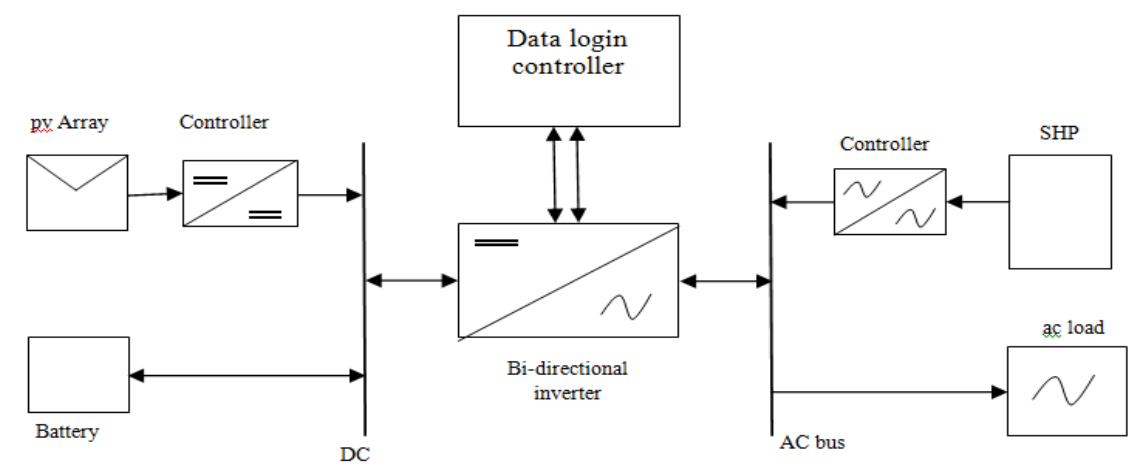

Fig 2.0 Typical SHP/Solar PV hybrid system

The PV array is connected to the dc bus through a controller/rectifier with a battery acting as a back up to store the excess energy. The SHP was connected to the ac bus through a controller. The bi-directional inverter acts as an inter switched between the ac-dc buses. Figure 2 shows a typical diagram of small hydropower/PV hybrid system for rural electrification.

\section{Energy Storage}

Electrical energy can be stored in batteries to provide for emergency cases such as in communications and educational equipment. The stochastic nature of renewable energy sources makes it so important for the use of appropriate storage and reconversion systems. Energy storage systems capable of smoothing out load fluctuations, making up for diurnal and seasonal variation in renewable energy sources and reacting to fast transient power quality needs contribute to efficient energy management of power systems [2,27].

\section{Roles of Educational Institutions}

If renewable energy is to have meaningful impacts,the personnel that is well trained in renewable energy technologies must be on ground for maintenance and even manufacture some of the few components for a sustainable energy system. Local educational institutions can be of tremendous assistance in this regards, by training personnel in their region to perform such jobs.

Educational institutions in developing countries can collaborate with their counterparts in the developed countries to assist them in the establishment of research centers with library, laboratory, and testing facilities where technological innovations can germinate and grow. They can also establish international training centers to bring scientists and engineers from various developing countries for short periods of time for intensive workshops and training. The ensuing multiplier effect in their own countries should lead to the buildup of an indigenous cadre of well qualified and trained people to shoulder responsibilities in this area $[14,15]$.

There is also the need to develop the interest of the students at a very early stage of their studies even at the 
primary and secondary school levels. Graduate students should also be tailored towards making more research and discoveries towards solving the problems posed by renewable energy technologies.Periodic short courses and workshops should be offered on various aspects of renewable energy sources aimed at motivating scientists, practicing engineers, industrialists, and entrepreneurs and some of the programs may even be designed for educating the general public on the beneficial impacts of the utilization of renewable energy resources.

\section{Conclusion}

Energization involves harnessing all possible available renewable resources in a way such that several forms of energy of different quality and characteristics provide a variety of energy. The key to implementing such system is to match energy needs with resources to maximize end-use efficiency.There is need for joint efforts between the communities, educational institutions and the government in the developing countries to actively involve themselves in the successful introduction of renewable energy technologies in the rural areas for the overall benefit of its entire citizenry.

Rural electrification is not the ideal solution in remote areas. Providing energy needs in various forms to match the needs allows the end users to benefit from such system. Integrated use of renewable energy sources will help overcome weakness of one resource by the strength of the other in some aspects. This will also provide job opportunities and upgrades socio-economic conditions of rural communities.

\section{References}

[1]. A.Sayigh, "Introduction and renewable energy update," Renewable Energy 2010, Sovereign Publication, UK, white paper,2010.

[2]. Timur Gill: Integrated Analysis of Hybrid Systems for Rural Electrification in Developing Countries. M.Tech thesis submitted to S Royal Institute of Technology, Stockholm, 2004.

[3]. R. Rammakumar and Hughes: Energy sources and rural development IEEE Transactions on Education vol.E24, No31981.

[4]. R.Ramakumar, Role of renewable energy in the development and electrification of remote and rural areas, IEEE Power Engineering Society General Meeting, Denver, CO, vol. 2, no. 10, pp. 2103-2105 Jun. 2004. doi: 10.1109/PES.2004.1373253

[5]. Thenapalan, Zhang,Can and Maddy :An overview of renewable energy technologies and Hydrogen Economy. International Conference on Renewable Energy and Power Qualities, Spain,2013.

[6]. Renewables: Global status report, Renewable Energy Policy Network for the 21st Century, Paris, France, 2011.

[7]. Renewables Global Status Report 2006 Update ,REN21, published 2006, accessed 2007-05-16

[8]. Biomass Energy Center, Biomassenergycentre.org.uk. Retrieved on 2012-02-28.

[9]. T.A. Volk, L.P. Abrahamson, E.H. White, E. Neuhauser, E. Gray, C.Demeter, C. Lindsey, J. Jarnefeld, D.J. Aneshansley, R. Pellerin and S. Edick (October 15-19, 2000). "Developing a Willow Biomass Crop Enterprise for Bioenergy and Bio-products in the United States" .Proceedings of Bioenergy 2000. Adam's Mark Hotel, Buffalo, New York, USA: North East Regional Biomass Program. OCLC 45275154 .Retrieved 2006-12-16.

[10]. Energy crops" .crops are grown specifically for use as fuel.BIOMASS Energy Centre. Retrieved 6 April 2013.

[11]. Frauke Urban and Tom Mitchell 2011. Climate change, disasters and electricity generation, London: OverseasDevelopment Institute and Institute of Development Studies

[12]. "Impact of Wind Power Generation in Ireland on the Operationof Conventional Plant and the Economic Implications" .eirgrid.com.February 2004. Archived from the original on 2011-08-25.Retrieved 22 November 2010.

[13]. Platt, Reg; Fitch-Roy, Oscar and Gardner: Paul Beyond the Bluster why Wind Power is an Effective Technology, Institute for Public Policy Research. August 2012

[14]. Watts, Jonathan \& Huang, Cecily:Winds Of Change Blow Through China As Spending On Renewable Energy Soars ,TheGuardian, March 19, 2012, revised on March 20, 2012. Retrieved January 4, 2012.

[15]. Hulazan, Ned:"Offshore wind power - Advantages and disadvantages" . Renewable Energy Articles. February 2011, Retrieved 9 April 2012.

[16]. How Geothermal energy works, Ucsusa.org. Retrieved on 2014-03-18.

[17]. D.L. Turcotte, G.Schubert, Geodynamics(2 ed.), Cambridge, England, UK: Cambridge University Press, pp. 136-137, ISBN 978-0521-66624-4, 2002.

[18]. F. Fridleifsson, B. Ingvar, Bertani, Ruggero; Huenges, Ernst; Lund, John W.; Ragnarsson, Arni; Rybach, Ladislaus (2008-02-11), O. Hohmeyer and T. Trittin, ed., The possible role and contribution ofgeothermal energy to the mitigation of climate change, IPCC Scoping Meeting on Renewable Energy Sources, Luebeck, Germany, pp. 59-80, retrieved 2009-04-06

[19]. E.W. Glassley, Geothermal Energy: Renewable Energy and the Environment, CRC Press, ISBN 9781420075700.pp 165-169, 2010

[20]. Cothran, Helen, Energy Alternatives, Greenhaven Press, ISBN 0737709049, pp59-67, 2010

[21]. F. Fridleifsson, B. Ingvar, "Geothermal energy for the benefit of the people", Renewable and Sustainable Energy Reviews 5 (3): 299, doi:10.1016/S1364-0321(01)00002-8, 2002

[22]. L. Lund, W. John, "Characteristics, Development and utilization of geothermal resources" ,Geo-Heat Centre QuarterlyBulletin(Klamath Falls, Oregon: Oregon Institute of Technology) 28 (2): 1-9,2007, retrieved 2009-04-16

[23]. V. F Thenakis, H.C Kim, "Land use and electricity generation: A life-cycle analysis". Renewable and Sustainable EnergyReviews13 (6-7): 1465. doi:10.1016/j.rser.2008.09.017, 2009

[24]. Castellano, Robert, Alternative Energy Technologies. p. 26. ISBN 978-2-8130-0076-7, 2012.

[25]. W.YiboandHonghua: Research and Practice of Designing Hydro/Photovoltaic Hybrid Power System in Microgrid. IEEE publications, 2013.

[26]. ESHA: The European Small hydropower Association, small hydropower engineering: A wide area of innovations for Green power generation. Available \{Online $\}$ :http://www.shp/publications.html.2010

[27]. A.B. Onyemaechi and I Charles: Small hydropower projects for rural electrification in Nigeria's developer's perspective. International Journal of Innovative Technology and Exploring Engineering (IJITEEE), vol-3, issues-5, 2013.

[28]. J.S.MajidKirmani,M.Rizwan: Techno- Economic Feasibility Analysis of Solar Photovoltaic Power Generation: A Review . Smart Grid and Renewable Energy, 2012. 
[29]. Mills, David (2004). "Advances in solar thermal electricity technology". Solar Energy 76 (1-3): 19-31.doi:10.1016/S0038092X(03)00102-6 .

[30]. Andrew Blakers and Klaus Weber, "The Energy Intensity of Photovoltaic Systems" , Centre for Sustainable Energy Systems, Australian National University, 2000.

[31]. Š́ri M., Huld T.A., Dunlop E.D. Ossenbrink H.A., 2007. Potential of solar electricity generation in the European Union member states and candidate countries. Solar Energy, 81, 1295-1305

[32]. A.Roger, Messager and J.Venture: Photovoltaic Systems Engineering, $3^{\text {rd }}$ Ed, New York: CRC Press, 2010.

[33]. "Small hydro in Canada" .Canmetenergy-canmetenergie.nrcanrncan. gc.ca. 2009-03-23. Retrieved 2013-10-16.

[34]. N. Crettenand, "The facilitation of mini and small hydropower in Switzerland: shaping the institutional framework. With a particular focus on storage and pumped-storage schemes". EcolePolytechnique, 2012Fédérale de Lausanne (EPFL). PhD Thesis $\mathrm{N}^{\circ}$ 5356. Infoscience.epfl.ch.

[35]. A.K, Akella R.P. Sanni, M.P. Shama: Development of Sizing and Cost Analysis for Integrated Renewable energy System in Study Area, (2010).

[36]. G.D. Burch: Hybrid renewable energy systems, US DOE, Natural Gas /Renewable Energy Workshops, Golden, CO,2001.

[37]. N.RahmanChewdbury ,S.E.Reza,T.AhmedNitol and Abd-Al-Fattan-IbneMahabub:'Present Scenario of Renewable Energy in Bangladesh and a Proposed Hybrid System to Minimize Power Crisis in Remote Area.' International Journal of Renewable Energy Research, 2012.

[38]. D. Bashir: Hydrological studies for small hydropower planning, a paper presented at training of trainers workshop on Small hydropower development Initiative and capacity building. 2003

[39]. Hiremath,Kumar,Balachandra and Ravindramath: Implications of Decentralized Energy Planning for Rural India. Journal of Sustainable Energy and Environment 2 31-34,2011.

[40]. Mahdi Sadiiqi: Basic design and cost optimization of a hybrid power system in rural communities in Afghanistan. M.Sc.thesis submitted to Kansas State University, Kansas, Afghanistan, 2012.

[41]. R.I.Ramakumr, K.Abouzhr,K.Krishman, Ashenayi: Design Scenarios for Integrated Renewable energy Systems. IEEE Power Engineering Society.1995.

[42]. R.Ramakumar: Energizing rural areas of developing countries using IRES, "Proceedings of 31st Intersociety Energy Conversion Engineering Conference, vol.3, pp. 1536-1541, Aug.1996. 